\title{
PERAN KEPUASAN KONSUMEN MEMEDIASI HUBUNGAN KUALITAS PRODUK DAN PERSEPSI HARGA DENGAN KEPUTUSAN PEMBELIAN ULANG
}

\author{
Ida Ayu Prayoni ${ }^{1}$ \\ Ni Nyoman Rsi Respati ${ }^{2}$ \\ ${ }^{1,2}$ Fakultas Ekonomi dan Bisnis Universitas Udayana, Bali, Indonesia \\ email: prayoni0198@gmail.com
}

\begin{abstract}
ABSTRAK
Penelitian ini bertujuan untuk mengetahui pengaruh kualitas produk dan persepsi harga terhadap kepuasan konsumen dan keputusan pembelian ulang pada konsumen yang membeli dan menggunakan pasta gigi Pepsodent. Penelitian ini dilakukan di Kota Denpasar dengan ukuran sampel sebesar 105 orang responden dengan metode non-probability berbentuk purposive sampling. Pengumpulan data dilakukan melalui penyebaran kuesioner dengan indikator sebanyak 15 yang diukur menggunakan skala Likert. Teknik analisis data yang digunakan dalam penelitian ini yaitu teknik analisis jalur dengan disertai uji asumsi klasik dan uji sobel. Hasil penelitian menyatakan bahwa variabel kepuasan konsumen, variabel kualitas produk dan variabel persepsi harga berpengaruh positif dan signifikan terhadap keputusan pembelian ulang.

Kata kunci: kualitas produk, persepsi harga, kepuasan konsumen, keputusan pembelian ulang
\end{abstract}

\begin{abstract}
This study aims to determine the effect of product quality and price perception on consumer satisfaction and repurchase decisions on consumers who buy and use Pepsodent toothpaste. This research was conducted in Denpasar City with a sample size of 105 respondents with non-probability methods in the form of purposive sampling. Data collection was carried out through questionnaires with as many as 15 indicators measured using a Likert scale. Data analysis techniques used in this study are path analysis techniques with classical assumption test and sobel test. The results of the study stated that the variables of customer satisfaction, product quality variables and price perception variables had a positive and significant effect on repurchase decisions.

Keywords: product quality, price perception, customer satisfaction, repeat purchase decisions
\end{abstract}




\section{PENDAHULUAN}

Perkembangan teknologi, informasi dan industrialisasi membuat banyak konsumen bermunculan sebagai pelaku-pelaku bisnis baru. Suatu peluang dan tantangan baru bagi perusahaan-perusahaan yang ada khususnya dalam rangka pemenuhan kebutuhan dan keinginan konsumen yang saat ini terus berkembang dalam mendapatkan suatu produk. Perusahan memiliki peluang untuk memperluas segmen pasarnya dan mengembangkan kualitas produknya, tetapi dalam hal ini perusahaan dihadapkan pada persaingan yang sangat ketat perusahaan-perusahaan berusaha menawarkan kepuasan kepada konsumen dalam menentukan keputusan pembelian masing-masing produknya serta kemampuan menjual yang lebih baik. Persaingan dalam memproduksi pasta gigi dengan keunggulan yang hampir sama sudah sangat ketat, banyak sekali bermunculan merek-merek pasta gigi baru, baik yang diproduksi dengan skala kecil atau lokal maupun skala yang besar atau nasional.

Pasta gigi merupakan salah satu produk pabrikan yang menjadi kebutuhan keluarga. Menggosok gigi merupakan salah satu perilaku hidup sehat, tidak hanya digunakan sebagai kebutuhan keluarga dan perilaku hidup sehat. Pasta gigi dapat digunakan sebagai modal kecantikan bagi seseorang (Berger dan Asa, 2011:06). Salah satu perusahan yang memproduksi pasta gigi di Indonesia adalah PT Unilever perusahaan yang memproduksi berbagai macam pasta gigi sampai saat ini perusahaan telah memproduksi beberapa merek yang memiliki keunggulan berbeda serta untuk segmen yang berbeda pula. Salah satu produknya adalah pasta gigi Pepsodent, produk ini juga menjadi produk unggulan dari PT. Unilever (Prasetyo, 2015).

Produk pasta gigi Pepsodent yang satu-satunya pasta gigi di Indonesia yang secara aktif mendidik dan mempromosikan kebiasaan menyikat gigi secara benar melalui program sekolah dan layanan pemeriksaan gigi gratis. Sejak itu Pepsodent telah melengkapi jajaran produknya melalui pembersihan dasar hingga pasta gigi dengan manfaat lengkap. Pepsodent telah menjadi market leader dan menguasai pangsa pasar untuk produk pasta gigi dan memiliki brand mix kuat serta akses ke konsumen sangatlah mudah (Putri, 2016).

Berdasarkan survei yang dilakukan oleh Top Brand Indexs tahun 2016-2018 terdapat data dalam kategori perawatan pribadi untuk pasta gigi sebagai berikut:

Tabel 1.

Data Top Brand Index (TBI), perawatan pribadi pasta gigi

\begin{tabular}{lccc}
\hline \multirow{2}{*}{ Merek } & \multicolumn{3}{c}{ Market Share } \\
\cline { 2 - 4 } & $\mathbf{2 0 1 6}$ & $\mathbf{2 0 1 7}$ & $\mathbf{2 0 1 8}$ \\
\hline Pepsodent & 77,6 & 78,7 & 64,6 \\
Close Up & 5,9 & 5,3 & 14,5 \\
Ciptadent & 7,0 & 6,7 & 5,1 \\
Formula & 4,8 & 5,2 & 4,8 \\
\hline
\end{tabular}

Sumber: www.topbrand-award.com, 2016-2018

Berdasarkan Tabel 1. menunjukkan bahwa pada tahun 2017 hanya produk Pepsodent yang mengalami kenaikan pangsa pasar pada posisi pertama dengan perolehan $78,7 \%$. Sedangkan produk Ciptadent mengalami penurunan pangsa pasar dengan perolehan $6,7 \%$ berada di urutan kedua. Produk Close Up mengalami 
penurunan pangsa pasar dengan perolehan $5,3 \%$ di urutan ketiga sementara pada tahun 2018 Close up mengalami kenaikan penjualan sebesar $14,5 \%$ sangat jauh dari penurunan yang terjadi sebelumnya dikarenakan adanya strategi pengiklanan baru yang dilakukan Close up dengan menggunakan model Indonesia sebagai brand endorser sehingga mampu menarik konsumen untuk mencoba produk Close Up (mix.co.id). Adanya kemajuan dari produk Formula yang sebelumnya tahun 2016 sebesar 4,8\% di tahun 2017 mengalami kenaikan sebesar 5,2\% walaupun pada posisi keempat. Penurunan pangsa pasar yang dialami Pepsodent pada tahun 2018 sebesar $14,5 \%$ menunjukkan adanya konsumen yang melakukan perpindahan ke merek pesaing dan adanya kejenuhan atau ketidakpuasan konsumen pada produk yang di konsumsi serta belum adanya varian produk baru yang ditawarkan Pepsodent kepada konsumen. Hal ini berarti menurunnya minat beli konsumen di masa mendatang terhadap pasta gigi Pepsodent dan rendahnya tingkat pembelian yang bisa membahayakan posisi merek pasta gigi di masa mendatang. Apabila hal ini diabaikan akan berdampak terhadap menurunnya angka penjualan dan kepemimpinan pasar berkurang bahkan menghilang. Dilihat dari hasil pra survey yang telah dilakukan oleh peneliti pada 15 responden, maka responden yang pernah membeli dan menggunakan pasta gigi Pepsodent sebanyak 10 responden menyatakan bahwa kualitas pasta gigi Pepsodent sangat memuaskan dan 5 responden menyatakan cukup setuju untuk menggunakan kembali pasta gigi Pepsodent serta menyarankan agar lebih meningkatkan kualitas dari pasta gigi Pepsodent.

Perkembangan pasta gigi di Kota Denpasar sangat pesat, hal ini dibuktikan dengan banyaknya merek pasta gigi yang memasuki supermarket maupun swalayan di Kota Denpasar sehingga membuat konsumen mempunyai banyak pilihan merek pasta gigi yang akan di konsumsinya, keadaan ini membuat konsumen berpindah dari merek yang satu ke merek yang lain.

Dalam hal ini konsumen sangat memperhatikan produk serta harga yang ditawarkan agar sesuai dengan persepsi yang diharapkan. Persepsi mempunyai pengaruh yang kuat bagi konsumen. Persepsi adalah suatu proses seorang individu dalam menyeleksi, mengorganisasikan, dan menterjemahkan stimulus-stimulus informasi yang datang menjadi suatu gambaran yang menyeluruh. Persepsi dibagi menjadi 4 kategori yakni, persepsi nilai, persepsi harga, persepsi kualitas dan persepsi citra merek. Salah satu faktor yang berpengaruh terhadap konsumen yaitu persepsi akan harga (Schiffman dan Kanuk, 2007). Harga dapat diartikan sebagai jumlah uang yang dibebankan untuk sebuah produk, jasa atau jumlah nilai konsumen dalam pertukaran untuk mendapatkan manfaat dalam menggunakan produk atau jasa (Kotler dan Amstrong, 2011). Berdasarkan pertimbangan tersebut para konsumen cenderung mempertimbangkan harga sebelum memutuskan untuk membeli sebuah produk.

Pernyataan ini mendukung penelitian yang mengatakan bahwa persepsi harga berpengaruh positif dan signifikan terhadap keputusan pembelian konsumen yang dipengaruhi oleh manfaat harga dan harga bersaing (Wifky et al, 2017). Berbeda dengan penelitian yang dilakukan oleh Anwar (2017), menyatakan bahwa persepsi harga secara parsial tidak berpengaruh positif dan tidak signifikan terhadap keputusan dipertimbangkan atas nilai suatu harga dan penilaian harga produk. 
Para konsumen dalam melakukan pembelian sebuah produk tentunya akan mempertimbangkan sisi kualitas yang sangat penting dalam keputusan pembelian konsumen. Menurut Amstrong (2012:283) kualitas produk adalah kemampuan sebuah produk dalam memperagakan fungsinya, hal ini termasuk keseluruhan durabilitas, reliabilitas, ketepatan, kemudahan pengoperasian, dan reparasi produk, juga atribut produk lainnya. Apabila kualitas produk yang dihasilkan baik maka konsumen cenderung melakukan pembelian kembali sedangkan bila kualitas produk tidak sesuai dengan yang diharapkan maka konsumen akan mengalihkan pembeliannya pada produk sejenis lainnya. Sering kali dibenak konsumen sudah terpatri bahwa produk perusahaan tertentu jauh lebih berkualitas dari pada produk pesaing dan konsumen membeli produk yang diyakini lebih berkualitas.

Kualitas produk menurut Tjiptono (2008) merupakan perpaduan antara sifat dan karakteristik yang menentukan sejauh mana keluaran dapat memenuhi prasyarat kebutuhan pelanggan atau menilai sampai seberapa jauh sifat dan karakteristik itu memenuhi kebutuhannya. Pernyataan ini didukung oleh penelitian sebelumnya yang menemukan bahwa kualitas produk berpengaruh terhadap pembelian yang didasari atas fitur, keandalan, estetika, kedayatahanan (Baruna, 2017). Kualitas produk saat ini sangatlah diperhatikan oleh konsumen terlebih lagi konsumen akan merasa kecewa apabila kualitas produk yang mereka beli ternyata tidak sesuai dengan harapannya. Konsumen menginginkan kualitas pasta gigi yang dapat memenuhi kebutuhan konsumsinya. Penelitian tersebut juga didukung oleh penelitian sebelumnya yang menyatakan bahwa kualitas produk yang dirasakan terbukti memiliki pengaruh yang signifikan dan positif terhadap keputusan yang dipengaruhi ketahanan produk dan servis yang di dapatkan (Cahyani et al, 2017). Namun penelitian ini bertentangan dengan penelitian yang dilakukan Pardede (2015) yang menunjukkan keputusan pembelian konsumen tidak dipengaruh secara positif dan signifikan oleh kualitas produk yang tidak dipengaruhi atas kinerja, kedayatahanan dan kesesuaian dengan spesifikasi.

Menurut Swastha \& Handoko (2012:140), keputusan pembelian ulang merupakan pembelian yang pernah dilakukan terhadap produk atau jasa yang sama dan akan membeli lagi untuk kedua atau ketiga kalinya. Keputusan pembelian ulang adalah keputusan untuk bersedia menggunakan produk atau jasa yang sama seperti sebelumnya yang menandakan bahwa produk atau jasa tersebut memenuhi harapan konsumen (Suryani, 2019). Pembelian ulang konsumen merupakan suatu proses pengintegrasian konsumen dalam membeli suatu barang atau jasa yang digunakan untuk memenuhi kebutuhan hidupnya sehingga perilaku membeli timbul karena didahului oleh adanya minat membeli. Minat untuk membeli muncul salah satunya disebabkan oleh persepsi yang didapatkan bahwa produk tersebut memiliki kualitas yang baik. Jadi minat membeli dapat diamati sejak sebelum perilaku membeli timbul dari konsumen (Isfiandi et al.,2019)

Kepuasan konsumen adalah perasaan seseorang yang baik atau buruk setelah membandingkan presentasi produk yang dirasakannya dengan harapan (Saleem et al., 2015) Kepuasan konsumen diketahui menjadi salah satu penyebab krusial dalam terciptanya keputusan untuk membeli produk yang mana akan meningkatkan keuntungan perusahaan. Kepuasan konsumen memungkinkan bisnis untuk mengukur dari perilaku pelanggan setelah mereka kontak dengan organisasi, seperti 
berkurangnya keluhan pelanggan, pembelian positif dari mulut ke mulut, dan meningkatkan volume pembelian (Hamza et al., 2014).

Semakin puas konsumen akan sebuah produk barang atau jasa yang ditawarkan kepada konsumen, maka akan menciptakan adanya keinginan untuk membeli atau mengkonsumsi kembali produk tersebut yang secara langsung akan meningkatkan tingkat penjualan perusahaan, sehingga keuntungan bisa lebih maksimal diterima oleh perusahaan yang mana pernyataan tersebut sejalan dengan penelitian yang dilakukan menyatakan bahwa variabel independen seperti persepsi harga dan kualitas produk memberikan pengaruh yang signifikan dan positif terhadap variabel dependen yaitu keputusan pembelian ulang yang diperkuat dengan minat konsumen membeli atau tidaknya suatu barang (Rizky, 2013)

Peneliti akan melakukan sebuah penelitian menggunakan beberapa variabel penelitian dengan melibatkan kepuasan konsumen sebagai variabel mediasi untuk mengetahui hasil dari hubungan kualitas produk dan persepsi harga dengan keputusan pembelian ulang.

Menurut Suvittawat (2015), Setyo (2017) menyatakan bahwa kualitas produk berpengaruh secara signifikan terhadap kepuasan konsumen. Artinya kualitas mempunyai dampak langsung pada kinerja produk atau jasa, oleh karena itu kualitas berhubungan erat dengan nilai dan kepuasan pelanggan. Pernyataan tersebut bertolak belakang dengan penelitian yang dilakukan Cahya (2018) enyatakan bahwakualitas produk tidak berpengaruh signifikan terhadap kepuasan pelanggan.

Penelitian sebelumnya yang dilakukan oleh (Widyasari et al., 2017) menyatakan bahwa kualitas produk berpengaruh positif dan signifikan terhadap kepuasan pelanggan. Yanti (2018) juga menyatakan bahwa kualitas produk berpengaruh signifikan dan positif terhadap kepuasan konsumen. Variabel kualitas produk dapat membuktikan hubungan secara langsung terhadap kepuasan konsumen.

$\mathrm{H}_{1}$ : Kualitas produk berpengaruh positif dan signifikan terhadap kepuasan konsumen.

Menurut (Deisy et al,. 2018) harga merupakan hal yang diperhatikan konsumen saat melakukan pembelian. Persepsi harga berpengaruh positif dan signifikan terhadap kepuasan konsumen (Resti \& Harry, 2016). Persepsi harga memiliki pengaruh positif terhadap kepuasan konsumen (Budiyanto, 2018).

Penelitian sebelumnya yang dilakukan oleh (Sedjai et al,. 2018) menemukan bahwa persepsi harga mempengaruhi kepuasan pelanggan, artinya bila pelanggan merasa puas terhadap harga yang di tawarkan maka akan dapat menarik pelanggan lebih banyak lagi. Pernyataan ini didukung oleh penelitan.

Berdasarkan hasil-hasil penelitian sebelumnya, maka rumusan hipotesis yang dapat diajukan yaitu:

$\mathrm{H}_{2}$ : Persepsi harga berpengaruh positif dan signifikan terhadap kepuasan konsumen

Hasil penelitian Fure et al. (2015), (Imam, 2015), yang mengemukakan bahwa kualitas produk yang tinggi, baik secara kuantitatif maupun kualitatif akan menyebabkan pembelian ulang menjadi semakin banyak dan berdampak terhadap pembelian ulang perusahaan secara menyeluruh sehingga kualitas produk akan memberikan pengaruh signifikan dan positif terhadap pembelian ulang. Namun 
penelitian tersebut bertentangan dengan penelitian yang dilakukan (Hartati, 2013) menyatakan bahwa kualitas produk berpengaruh tidak signifikan terhadap keputusan pembelian ulang sabun mandi Shinzui di Kota Palu.

Penelitian tersebut tidak sejalan dengan penelitian yang dilakukan Nofina (2015), (Nasith (2015) bahwa kualitas produk berpengaruh positif dan signifikan terhadap keputusan pembelian ulang.

$\mathrm{H}_{3}$ : Kualitas produk berpengaruh positif dan signifikan terhadap keputusan pembelian ulang.

Menurut Zahro (2017) harga berpengaruh positif dan signifikan terhadap keputusan pembelian ulang jilbab pada outlet Rabbani Collection di Bojonegoro. Namun pernyataan tersebut berbeda dengan yang ditemukan oleh Prabudi (2014) menunjukan bahwa persepsi harga berpengaruh tidak signifikan terhadap keputusan pembelian. Penelitian tersebut tidak sejalan dengan penelitian yang dilakukan oleh Nofina (2015) bahwa harga berpengaruh positif dan siginifikan terhadap keputusan pembelian ulang sepeda motor Honda.

Penelitian ini juga didukung oleh Apriyani (2013), Nasution (2018)menyatakan bahwa terdapat pengaruh yang positif dan signifikan antara harga terhadap keputusan pembelian ulang.

$\mathrm{H}_{4}$ : Persepsi harga berpengaruh positif dan signifikan terhadap keputusan pembelian ulang.

Menurut (Djumarno et al., 2018) mengemukakan peran mediasi yang signifikan dari kepuasan konsumen terjadi ketika variabel independen secara signifikan mempengaruhi variabel mediasi dan variabel mediasi yang signifikan pada variabel dependen. Utama et al,. 2015 kepuasan konsumen memiliki pengaruh positif dan signifikan terhadap keputusan pembelian ulang, didalam penelitian ini kepuasan konsumen disesuaikan dengan biaya manfaat yang diperoleh, kelengkapan barang yang ditawarkan, kesesuaian fisilitas yang ada dan tingkat perasaan konsumen setelah berbelanja.

Pernyataan tersebut sejalan dengan beberapa penelitian yag dilakukan oleh (Pamungkas et al., 2018), Nugrahanto (2015) dan Olii (2016) menyatakan bahwa kepuasan konsumen memberikan pengaruh yang signifikan terhadap keputusan pembelian ulang yang mengidentifikasikan bahwa konsumen sudah merasa puas terhadap sebuah produk.

Berdasarkan hasil-hasil penelitian sebelumnya, maka rumusan hipotesis yang dapat diajukan yaitu:

$\mathrm{H}_{5}$ : Kepuasan konsumen berpengarah positif dan signifikan terhadap keputusan pembelian ulang.

Menurut (Pardede, 2015) dalam penelitiannya menyatakan bahwa kualitas produk berpengaruh positif dan signifikan terhadap kepuasan konsumen. Berbeda dengan penelitian yang dilakukan Cahya (2018) menyatakan bahwa kualitas produk tidak berpengaruh signifikan terhadap kepuasan pelanggan.

Menurut (Bowo dkk., 2013) kualitas produk mempunyai pengaruh yang bersifat langsung terhadap kepuasan pelanggan dengan meningkatkan kemampuan suatu produk maka akan tercipta keunggulan bersaing sehingga pelanggan menjadi semakin puas yang artinya ada pengaruh positif dan signifikan terhadap kepuasan konsumen dan kualitas produk. Pernyataan tersebut didukung oleh Setyaningrum 
(2019) kualitas produk merupakan variabel yang paling berpengaruh terhadap keputusan pembelian ulang.

Berdasarkan hasil-hasil penelitian sebelumnya maka rumusan hipotesis yang dapat diajukan yaitu:

$\mathrm{H}_{6}$ : Peran kepuasan konsumen secara signifikan memediasi kualitas produk terhadap keputusan pembelian ulang.

Persepsi harga berpengaruh signifikan dan positif terhadap kepuasan konsumen dan keputusan pembelian yang artinya pandangan atau persepsi mengenai harga bagaimana pelanggan memandang harga tertentu tinggi, rendah, memiliki pengaruh yang kuat terhadap maksud membeli dan kepuasan membeli (Harjati \& Venesia, 2015) Persepsi harga berpengaruh positif dan signifikan terhadap kepuasan konsumen (Sari,2019). Menurut (Musa et al., 2018) konsumen dalam keputusan pembelian kembali yang didasarkan pada tipe kepribadian mereka.

Menurut Tengku (2016) mengatakan bahwa keputusan konsumen untuk pembelian dan mengonsumsi suatu produk sangat dipengaruhi oleh berbagai faktor, sebagai seorang individu, konsumsi suatu produk akan dipengaruhi oleh persepsi, proses pembelajaran dan memori, motivasi dan nilai, konsep diri, sikap, kepribadian dan gaya hidup. Sebagai pengambil keputusan hal ini akan tergantung dari tipe keputusan rutin atau jarang, situasi pembelian yang dihadapi, kelompok atau orang yang mempengaruhi dan menjadi acuan. Harga yang dipersepsikan mempengaruhi keputusan pembelian kembali terkait produk-produk (Widyastuti, 2017). Pernyataan tersebut sejalan dengan penelitian yang dilakukan (Sagita, 2013) menyatakan bahwa harga berpengaruh signifikan terhadap keputusan pembelian ulang produk.

$\mathrm{H}_{7}$ : Kepuasan konsumen secara signifikan memediasi persepsi harga dengan keputusan pembelian ulang.

\section{METODE PENELITIAN}

Penelitian ini dilakukan di Kota Denpasar yang merupakan ibu Kota Provinsi Bali. Kota Denpasar memiliki kepadatan penduduk sebanyak 788.598 orang berdasarkan data yang diperoleh dari Badan Pusat Statistik (BPS) Provinsi Bali tahun 2018. Padatnya penduduk berdampak pada tingginya kebutuhan masyarakat akan suatu produk yang mampu merawat kesehatan gigi yang dapat menunjang percaya diri dalam berbicara, napas menjadi wangi serta gigi agar tampak bersih berkilau.

Populasi dalam penelitian ini adalah konsumen yang sudah pernah menggunakan dan membeli pasta gigi Pepsodent di Kota Denpasar. Penentuan jumlah sampel, antara lain: ukuran sampel berkisar antara 30-500, untuk sampel yang dipecah menjadi beberapa kategori minimal sebanyak 30 sampel dalam kategori, penelitian multivariat ukuran sampel sebaiknya dikalikan 5-10 dibandingkan dengan jumlah indikator variabel di dalam studi. Penelitian ini menggunakan 15 indikator dan memilih angka 7 dari rentang ukuran sampel terbaik. Berdasarkan pertimbangan tersebut maka ukuran sampel penelitian ini di tetapkan sebanyak 105 responden. 
Dalam penelitian ini teknik analisis yang digunakan adalah teknik analisis jalur (path analysis). Analisis jalur digunakan untuk menentukan pola hubungan antara tiga atau lebih dan tidak dapat digunakan untuk mengkonfirmasi atau menolak hipotesis.

\section{HASIL DAN PEMBAHASAN}

Uji validitas bertujuan untuk memeriksa apakah kuesioner sebagai instrumen penelitian sudah tepat untuk mengukur indikator dalam penelitian sehingga dapat dikatan valid. Apabila koefisien korelasi $\geq 0,30$ maka instrumen tersebut dapat dikatakan valid. Hasil uji validitas instrumen penelitian disajikan pada Tabel 2.

Tabel 2.

Hasil Uji Validitas

\begin{tabular}{|c|c|c|c|c|}
\hline Variabel & $\begin{array}{l}\text { Indikator } \\
\text { Penelitian }\end{array}$ & Instrumen & $\begin{array}{c}\text { Pearson } \\
\text { Correlation }\end{array}$ & Ket. \\
\hline & Kinerja & $\mathrm{X}_{1.1}$ & 0,866 & Valid \\
\hline Kualitas & Keistimewaan & $\mathrm{X}_{1.2}$ & 0,891 & Valid \\
\hline \multirow[t]{2}{*}{ Produk (X1) } & Kehandalan & $\mathrm{X}_{1.3}$ & 0,837 & Valid \\
\hline & Daya tahan & $\mathrm{X}_{1.4}$ & 0,888 & Valid \\
\hline \multirow{3}{*}{$\begin{array}{l}\text { Persepsi } \\
\text { Harga (X2) }\end{array}$} & Keterjangkauan harga & $\mathrm{X}_{2.1}$ & 0,898 & Valid \\
\hline & Kesesuaian manfaat & $\mathrm{X}_{2.2}$ & 0,802 & Valid \\
\hline & Daya saing harga & $\mathrm{X}_{2.3}$ & 0,905 & Valid \\
\hline \multirow{3}{*}{$\begin{array}{l}\text { Keputusan } \\
\text { Pembelian } \\
\text { Ulang (Y1) }\end{array}$} & Kesadaran pembelian awal & $\mathrm{Y}_{1.1}$ & 0,892 & Valid \\
\hline & Evaluasi pasca-pembelian & $\mathrm{Y}_{1.2}$ & 0,830 & Valid \\
\hline & $\begin{array}{l}\text { Keputusan membeli } \\
\text { kembali/ulang }\end{array}$ & $\mathrm{Y}_{1.3}$ & 0,925 & Valid \\
\hline \multirow{5}{*}{$\begin{array}{l}\text { Kepuasan } \\
\text { Konsumen } \\
\text { (M) }\end{array}$} & $\begin{array}{l}\text { Terpenuhinya harapan } \\
\text { konsumen }\end{array}$ & $\mathbf{M}_{1.1}$ & 0,852 & Valid \\
\hline & $\begin{array}{l}\text { Keinginan untuk } \\
\text { menggunakan }\end{array}$ & $\mathbf{M}_{1.2}$ & 0,852 & Valid \\
\hline & $\begin{array}{l}\text { Merekomendasikan } \\
\text { pihak lain }\end{array}$ & $\mathbf{M}_{1.3}$ & 0,853 & Valid \\
\hline & Loyal & $\mathbf{M}_{1.4}$ & 0,872 & Valid \\
\hline & Reputasi yang baik & $\mathbf{M}_{1.5}$ & 0,904 & Valid \\
\hline
\end{tabular}

Hasil uji validitas instrumen penelitian yang disajikan dalam Tabel 2. menunjukkan bahwa seluruh indikator pernyataan dalam variabel kualitas produk, persepsi harga, kepuasan konsumen, dan keputusan pembelian ulang memiliki pearson correlation lebih besar dari 0,30 sehingga seluruh indikator tersebut telah memenuhi syarat validitas data.

Uji reliabilitas menunjukkan sejauh mana suatu alat ukur dapat dipercaya atau dapat diandalkan. Apabila suatu alat pengukuran dipakai dua kali untuk mengukur gejala yang sama dan hasil pengukuran yang diperoleh relatif konsisten, maka alat pengukuran tersebut reliable. Suatu instrumen dapat dikatakan reliabel apabila nilai Cronbach's Alpha $\geq 0,60$. Hasil pengujian reliabilitas instrumen dapat dilihat pada Tabel 3. 
Tabel 3.

Hasil Uji Reliabilitas

\begin{tabular}{lcc}
\hline Variabel & Cronbach's Alpha & Keterangan \\
\hline Kualitas Produk (X1) & 0,893 & Reliabel \\
Persepsi Harga (X2) & 0,838 & Reliabel \\
Keputusan Pembelian Ulang (Y1) & 0,842 & Reliabel \\
Kepuasan Konsumen (M) & 0,916 & Reliabel \\
\hline
\end{tabular}

Sumber: Data diolah, 2019

Tabel 3. yang menunjukkan bahwa keempat instrumen penelitian yaitu variabel kualitas produk, persepsi harga, kepuasan konsumen, dan keputusan pembelian ulang memiliki koefisien Cronbach's Alpha lebih besar dari 0,60 sehingga pernyataan pada kuesioner tersebut reliabel.

Teknik analisi jalur (path analysis) merupakan teknik analisis data yang digunakan dalam penelitian ini. Analisis jalur digunakan untuk menentukan pola hubungan antar tiga atau lebih dan tidak dapat digunakan untuk mengkonfirmasi atau menolak hipotesis. Berikut adalah hasil dari analisis jalur dalam penelitian ini:

Perhitungan koefisien jalur dilakukan dengan menggunakan SPSS 25. Hasil dari pengolahan data untuk persamaan regresi 1 disajikan dalam Tabel 4. sebagai berikut:

Tabel 4.

Hasil Analisis Jalur Persamaan Regresi 1

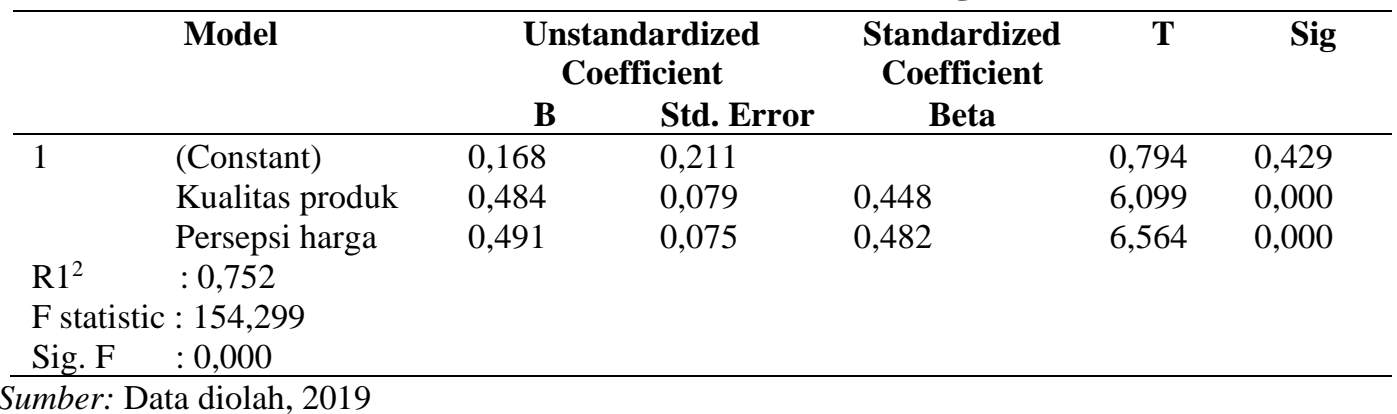

Berdasarkan data yang disajikan pada Tabel 4. maka persamaan strukturalnya dapat disusun sebagai berikut:

$$
\mathrm{M}=0,448 \mathrm{X}_{1}+0,482 \mathrm{X}_{2}
$$

Nilai $\beta_{1}$ adalah sebesar 0.448 memiliki arti kualitas produk berpengaruh positif terhadap kepuasan konsumen, dengan kata lain jika faktor kualitas produk meningkat maka kepuasan konsumen meningkat.

Nilai $\beta_{2}$ adalah sebesar 0.482 memiliki arti persepsi harga berpengaruh positif terhadap kepuasan konsumen, dengan kata lain jika faktor persepsi harga meningkat maka kepuasan konsumen meningkat. Hasil pengolahan data untuk persamaan regresi 2 disajikan dalam tabel 5 sebagai berikut: 
Tabel 5.

Hasil Analisis Jalur Persamaan Regresi 2

\begin{tabular}{|c|c|c|c|c|c|c|}
\hline \multirow{2}{*}{\multicolumn{2}{|c|}{ Model }} & \multicolumn{2}{|c|}{$\begin{array}{l}\text { Unstandardized } \\
\text { Coefficient }\end{array}$} & \multirow{2}{*}{$\begin{array}{c}\text { Standardized } \\
\text { Coefficient } \\
\text { Beta } \\
\end{array}$} & \multirow[t]{2}{*}{$\mathrm{t}$} & \multirow[t]{2}{*}{ Sig } \\
\hline & & $\mathrm{B}$ & Std. Error & & & \\
\hline \multirow[t]{4}{*}{1} & (Constant) & $-0,130$ & 0,210 & & $-0,616$ & 0,539 \\
\hline & Kualitas produk & 0,280 & 0,092 & 0,248 & 3,053 & 0,003 \\
\hline & Persepsi harga & 0,214 & 0,088 & 0,200 & 2,421 & 0,017 \\
\hline & $\begin{array}{l}\text { Kepuasan } \\
\text { konsumen }\end{array}$ & 0,520 & 0,098 & 0,496 & 5,295 & 0,000 \\
\hline $\mathrm{R}^{2}$ & $: 0,780$ & & & & & \\
\hline & atistic : 119,314 & & & & & \\
\hline & $\mathrm{F} \quad: 0,000$ & & & & & \\
\hline
\end{tabular}

Berdasarkan data yang disajikan pada Tabel 5 maka persamaan strukturalnya dapat disusun sebagai berikut:

$\mathrm{Y}=\beta_{3} \mathrm{X}_{1}+\beta_{4} \mathrm{X}_{2}+\beta_{5} \mathrm{M}+\mathrm{e}_{2}$

$\mathrm{Y}=0,248 \mathrm{X}_{1}+0,200 \mathrm{X}_{2}+0,496 \mathrm{M}$

Nilai $\beta_{3}$ adalah sebesar 0,248 memiliki arti kualitas produk berpengaruh positif terhadap keputusan pembelian ulang, dengan kata lain jika faktor kualitas produk meningkat maka keputusan pembelian ulang meningkat.

Nilai $\beta_{4}$ adalah sebesar 0,200 memiliki arti persepsi harga berpengaruh positif terhadap keputusan pembelian ulang, dengan kata lain jika faktor kualitas produk meningkat maka keputusan pembelian ulang meningkat.

Nilai $\beta_{5}$ adalah sebesar 0,496 memiliki arti kepuasan konsumen berpengaruh positif terhadap keputusan pembelian ulang, dengan kata lain jika faktor kepuasan konsumen meningkat maka keputusan pembelian ulang meningkat.

Berdasarkan persamaan regresi 1 dan 2 diketahui nilai dari $\mathrm{R}_{1}{ }^{2}=0,752$ dan $\mathrm{R}_{2}{ }^{2}$ $=0,780$ maka nilai error untuk masing-masing persamaan dihitung sebagai berikut:

$$
\begin{aligned}
& \mathrm{e}=\sqrt{1-R^{2}} \ldots \ldots \ldots \ldots \ldots \ldots \ldots \ldots \ldots \\
& \mathrm{e}_{1}=\sqrt{1-R 1^{2}}=\sqrt{1-0,752}=0,498 \\
& \mathrm{e}_{2}=\sqrt{1-R 2^{2}}=\sqrt{1-0,780}=0,469
\end{aligned}
$$

Berdasarkan perhitungan di atas, diketahui besarnya pengaruh $\mathrm{e}_{1}=0,498$ dan nilai dari $\mathrm{e}_{2}=0,469$ dari nilai $\mathrm{e}_{1}$ dan $\mathrm{e}_{2}$ yang telah diketahui maka koefisien determinansi total dapat dihitung sebagai berikut:

$$
\begin{aligned}
\mathrm{R}^{2} \mathrm{~m} & =1-\left(\mathrm{Pe}_{1}\right)^{2}\left(\mathrm{Pe}_{2}\right)^{2} \ldots \ldots \\
& =1-(0,498)^{2}(0,469)^{2} \\
& =1-(0,248)(0,220) \\
& =1-0,055 \\
& =0,945
\end{aligned}
$$

Koefisien determinansi sebesar 0,945 artinya sebesar 94,5 persen variabel keputusan pembelian ulang dipengaruhi oleh variabel kepuasan konsumen, kualitas produk dan persepsi harga, sedangkan sisanya 5,5 persen dijelaskan oleh faktor lain yang tidak dimasukkan kedalam model. 
Hasil dari analisis diketahui pengaruh kualitas produk terhadap kepuasan konsumen memuliki koefisien $\beta_{1}=0,448$ dan $p$ value sebesar 0,000 nilai koefisien $\beta_{1}>0$ dan $p$ value $\leq 0,05$ sehingga $\mathrm{H}_{1}$ diterima dan $\mathrm{H}_{0}$ ditolak. Berarti kualitas produk berpengaruh positif dan signifikan terhadap kepuasan konsumen.

Hasil dari analisis diketahui pengaruh persepsi harga terhadap kepuasan konsumen memiliki koefisien $\beta_{2}=0,482$ dan $p$ value sebesar 0,000 nilai koefisien $\beta_{2}>0$ dan $p$ value $\leq 0,05$ sehingga $\mathrm{H}_{2}$ diterima dan $\mathrm{H}_{0}$ ditolak. itu berarti persepsi harga berpengaruh positif dan signifikan terhadap kepuasan konsumen.

Hasil dari analisis diketahui pengaruh kualitas produk terhadap keputusan pembelian ulang memiliki koefisien $\beta_{3}=0,248$ dan $p$ value sebesar 0,003 nilai koefisien $\beta_{3}>0$ dan $p$ value $\leq 0,05$ sehingga $\mathrm{H}_{3}$ diterima dan $\mathrm{H}_{0}$ ditolak. itu berarti kualitas produk berpengaruh positif dan signifikan terhadap keputusan pembelian ulang.

Hasil pada Tabel 5. diketahui pengaruh persepsi harga terhadap keputusan pembelian ulang memiliki koefisien $\beta_{4}=0,200$ dan $p$ value sebesar 0,017 nilai koefisien $\beta_{4}>0$ dan $p$ value $\leq 0,05$ sehingga $\mathrm{H}_{4}$ diterima dan $\mathrm{H}_{0}$ ditolak. itu berarti persepsi harga berpengaruh positif dan signifikan terhadap keputusan pembelian ulang. Hasil pada Tabel 5. diketahui pengaruh kepuasan pelanggan terhadap keputusan pembelian ulang memiliki koefisien $\beta_{5}=0,496$ dan $p$ value sebesar 0,000 . Nilai koefisien $\beta_{5}>0$ dan $p$ value $\leq 0,05$ sehingga $\mathrm{H}_{5}$ diterima dan $\mathrm{H}_{0}$ ditolak. itu berarti kepuasan konsumen berpengaruh positif dan signifikan terhadap keputusan pembelian ulang.

Perhitungan pengaruh antar variabel ditunjukkan pada Tabel 6. berikut:

Tabel 6.

Pengaruh langsung, pengaruh tidak langsung dan pengaruh total kualitas produk $\left(\mathrm{X}_{1}\right)$, persepsi harga $\left(\mathrm{X}_{2}\right)$, kepuasan konsumen $(\mathrm{M})$, dan keputusan pembelian ulang $(Y)$.

\begin{tabular}{cccc}
\hline $\begin{array}{c}\text { Pengaruh } \\
\text { Variabel }\end{array}$ & $\begin{array}{c}\text { Pengaruh } \\
\text { Langsung }\end{array}$ & $\begin{array}{c}\text { Pengaruh Tidak Langsung Melalui } \\
\text { Kepuasan Konsumen }\end{array}$ & Pengaruh Total \\
\hline $\mathrm{X}_{1} \longrightarrow \mathrm{M}$ & 0,448 & - & 0,448 \\
$\mathrm{X}_{2} \longrightarrow \mathrm{M}$ & 0,482 & - & 0,482 \\
$\mathrm{X}_{1} \longrightarrow \mathrm{Y}$ & 0,248 & 0,222 & 0,470 \\
$\mathrm{X}_{2} \longrightarrow \mathrm{Y}$ & 0,200 & 0,239 & 0,439 \\
$\mathrm{M} \longrightarrow \mathrm{Y}$ & 0,498 & - & 0,498 \\
\hline
\end{tabular}

Sumber: Data diolah, 2019

Data tersebut menunjukkan bahwa kualitas produk berpengaruh langsung terhadap keputusan pembelian ulang sebesar 24,8 persen, dengan dimediasi kepuasan konsumen maka didapatkan pengaruh tidak langsung sebesar 22,2 persen, dan pengaruh total sebesar 47 persen. Hasil tersebut menunjukkan bahwa kepuasan konsumen memediasi hubungan kualitas produk terhadap keputusan pembelian ulang secara parsial.

Tabel 6. juga menunjukkan pengaruh langsung variabel persepsi harga terhadap keputusan pembelian ulang sebesar 20 persen serta pengaruh tidak langsung yang dimediasi kepuasan konsumen memperoleh nilai beta sebesar 23,9 persen, hal tersebut menunjukkan bahwa kepuasan konsumen memediasi pengaruh 
persepsi harga terhadap keputusan pembelian ulang dengan pengaruh total sebesar 43,9 persen. Hasil tersebut menunjukkan bahwa kepuasan konsumen memediasi secara parsial hubungan pesepsi harga terhadap keputusan pembelian ulang.

Uji normalitas ini bertujuan untuk mngetahui apakah residual model regresi yang dibuat berdistribusi normal atau tidak dapat dilakukan dengan menggunakan uji Kolmogorov Smirnov. Apabila koefisien Asymp. Sig. (2-tailed) lebih besar dari 0,05 maka data tersebut dikatakan berdistribusi normal.

Tabel 7.

Hasil uji normalitas persamaan regresi 1

\begin{tabular}{cc}
\hline & Unstandardized Residual \\
\hline $\mathrm{N}$ & 105 \\
Kolmogorov Smirnov & 0.933 \\
Asymp. Sig. (2-tailed) & 0.349 \\
\hline Sumber: Data diolah, 2019
\end{tabular}

Berdasarkan Tabel 7. maka dapat dilihat bahwa nilai Kolmogorov Smirnov (K-S) sebesar 0,933 sedangkan nilai Asymp. Sig (2-tailed) sebesar 0,349 Hasil tersebut mengindikasikan bahwa model persamaan regresi tersebut berdistribusi normal karena nilai Asymp. Sig (2-tailed) sebesar 0,349 dimana lebih besar dari nilai Alpha yaitu 0,05.

Tabel 8.

Hasil uji normalitas persamaan regresi 2

\begin{tabular}{cc}
\hline & Unstandardized Residual \\
\hline $\mathrm{N}$ & 105 \\
Kolmogorov Smirnov & 1.160 \\
Asymp. Sig. (2-tailed) & 0.136 \\
\hline
\end{tabular}

Sumber: Data diolah, 2019

Berdasrkan Tabel 8. maka dapat dilihat bahwa nilai Kolmogorov Smirnov (KS) sebesar 1,160 sedangkan nilai Asymp sig. (2-tailed) sebesar 0,136 Hasil tersebut mengidikasikan bahwa model persamaan regresi tersebut berdistribusi normal karena nilai Asymp Sig. (2-tailed) sebesar 0,136 dimana lebih besar dari nilai Alpha yaitu 0,05 .

Uji multikolinieritas bertujuan menguji apakah pada model regresi ditemukan adanya korelasi antar variabel bebas. Adanya multikolinierotas dapat dilihat dari nilai tolerance atau variance inflaction factor (VIF). Jika nilai tolerance lebih dari 10 persenatau variance inflaction factor (VIF) kurang dari 10, maka dapat dikatakan tidak ada multikolinieritas.

Tabel 9.

Hasil uji multikolineritas persamaan regresi 1

\begin{tabular}{lcc}
\hline \multicolumn{1}{c}{ Variabel } & Tolerance & VIF \\
\hline Kualitas produk & 0,452 & 2,211 \\
Persepsi harga & 0,452 & 2,211 \\
\hline Sumber: Data diolah, 2019 & &
\end{tabular}


Berdasarkan Tabel 9. dapat dilihat nilai tolerance atau variance inflaction factor (VIF) dari variabel kulitas produk dan persepsi harga. Nilai tersebut menunjukkan bahwa nilai tolerance utnuk setiap variabel lebih dari 10 persen dan nilai variance inflaction factor (VIF) lebih kecil dari 10 yang berarti model persamaan regresi 1 bebas dari multikolinieritas.

Tabel 10.

Hasil uji multikolineritas persamaan regresi 2

\begin{tabular}{lcc}
\hline \multicolumn{1}{c}{ Variabel } & Tolerance & VIF \\
\hline Kualitas produk & 0,331 & 3,018 \\
Persepsi harga & 0,318 & 3,145 \\
Kepuasan konsumen & 0,248 & 4,025 \\
\hline
\end{tabular}

Sumber: Data diolah, 2019

Berdasarkan Tabel 10. dapat dilihat nilai tolerance atau variance inflaction factor (VIF) dari variabel kulitas produk, persepsi harga dan kepuasan konsumen. Nilai tersebut menunjukkan bahwa nilai tolerance utnuk setiap variabel lebih dari 10 persen dan nilai variance inflaction factor (VIF) lebih kecil dari 10 yang berarti model persamaan regresi 2 bebas dari multikolinieritas.

Uji heteroskedastisitas bertujuan untuk mengetahui apakah dalam model regresi terjadi ketidaksamaan varians dari residual satu pengamatan lain yang dilakukan dengan uji Glejser. Jika tidak ada satu pun variabel bebas yang berpengaruh signifikan terhadap nilai absolut residual atau nilai signifikansinya di atas 0,05 maka tidak terdapat gejala heteroskedastisitas.

Tabel 11.

Hasil uji heteroskedastisitas persamaan regresi 1

\begin{tabular}{|c|c|c|c|c|c|c|}
\hline & \multirow[t]{2}{*}{ Model } & \multicolumn{2}{|c|}{$\begin{array}{l}\text { Unstandardized } \\
\text { Coefficient }\end{array}$} & \multirow{2}{*}{$\begin{array}{c}\text { Standardized } \\
\text { Coefficient } \\
\text { Beta }\end{array}$} & \multirow{2}{*}{$\mathbf{t}$} & \multirow{2}{*}{ Sig } \\
\hline & & B & $\begin{array}{c}\text { Std. } \\
\text { Error }\end{array}$ & & & \\
\hline \multirow[t]{3}{*}{1} & (Constant) & 0,670 & 0.132 & & 5.073 & 0.000 \\
\hline & Kualitas produk & -0.059 & 0.050 & -0.166 & -1.187 & 0,238 \\
\hline & Persepsi harga & -0.054 & 0.047 & -0.163 & -1.165 & 0,247 \\
\hline
\end{tabular}

Sumber: Data diolah, 2019

Pada Tabel 11. dapat dilihat bahwa nilai signifikansi dari variabel kualitas produk sebesar 0,238 lebih besar dari 0,05 dan variabel persepsi harga sebesar 0,247 lebih besar dari 0,05 yang berarti tidak terdapat pengaruh antara variabel bebas terhadap absolut residual. Dengan demikian model yang dibuat tidak mengandung gejala heteroskedastisitas.

Pada Tabel 12. dapat dilihat bahwa nilai signifikansi dari variabel kualitas produk sebesar 0,288 lebih besar dari 0,05, variabel persepsi harga sebesar 0,637 lebih besar dari 0,05 dan variabel kepuasan konsumen sebesar 0,614 lebih besar dari 0,05 yang berarti tidak terdapat pengaruh antara variabel bebas terhadap absolut residual. Dengan demikian model yang dibuat tidak mengandung gejala heteroskedastisitas. 
Tabel 12.

Hasil uji heteroskedastisitas persamaan regresi 2

\begin{tabular}{|c|c|c|c|c|c|c|}
\hline & Model & $\begin{array}{r}\text { Unsta } \\
\text { Co }\end{array}$ & ized & $\begin{array}{c}\text { Standardized } \\
\text { Coefficient }\end{array}$ & $t$ & Sig \\
\hline & & B & $\begin{array}{c}\text { Std. } \\
\text { Error }\end{array}$ & Beta & $\mathrm{t}$ & SIg \\
\hline 1 & (Constant) & 0,495 & 0,127 & & 3,892 & 0,000 \\
\hline & Kualitas produk & $-0,059$ & 0,056 & $-0,181$ & $-1,069$ & 0,288 \\
\hline & Persepsi harga & 0,025 & 0,054 & 0,082 & 0,473 & 0,637 \\
\hline & Kepuasan & $-0,030$ & 0,059 & $-0,099$ & $-0,506$ & 0,614 \\
\hline & konsumen & & & & & \\
\hline & Dependent Varia & Absres 2 & & & & \\
\hline
\end{tabular}

Sumber: Data diolah, 2019

Uji sobel merupakan teknik analisis untuk menguji signifikansi dan hubungan tidak langsung antara variabel independen dengan variabel dependen yang dimediasi oleh variabel mediator. Uji sobel dihitung dengan menggunakan aplikasi Microsoft Excel 2010. Nilai koefisien z jika lebih dari 1,96 maka variabel kepuasan konsumen dalam penelitian ini dinilai secara signifikan mampu memediasi hubungan pengaruh kualitas produk dan persepsi harga terhadap keputusan pembelian ulang.

Peran kepuasan konsumen memediasi pengaruh kualitas produk terhadap keputusan pembelian ulang.

Uji sobel dihitung dengan persamaan sebagai berikut:

$\mathrm{z}=\frac{\mathrm{a} \cdot \mathrm{b}}{\sqrt{\mathrm{a}^{2} \mathrm{Sb}^{2}+\mathrm{b}^{2} \mathrm{Sa}^{2}+\mathrm{Sa}^{2} \mathrm{Sb}^{2}}}$.

Keterangan:

a $=0,448$

$\mathrm{S}_{\mathrm{a}}=0,079$

$\mathrm{b}=0,496$

$\mathrm{S}_{\mathrm{b}}=0,098$

$\mathrm{Z}=\frac{(0,448)(0,496)}{\sqrt{(0,448)^{2}(0,098)^{2}+(0,498)^{2}(0,079)^{2}+(0,079)^{2}(0,098)^{2}}}$

$\mathrm{Z}=\frac{0,2222}{0,0594}$

$\mathrm{z}=3,7438$

Hasil uji sobel yang dihitung menunjukkan bahwa nilai koefisien $\mathrm{z}$ adalah $3,7438>1,96$ dengan tingkat signifikansi $0,0002<0,05$ sehingga $\mathrm{H}_{0}$ ditolak dan $\mathrm{H}_{1}$ diterima. Hasil tersebut mengartikan bahwa kepuasan konsumen sebagai variable mediasi dinilai secara signifikan mampu memediasi pengaruh kualitas produk terhadap keputusan pembelian ulang.

Peran kepuasan konsumen memediasi pengaruh persepsi harga terhadap keputusan pembelian ulang

Uji sobel dihitung dengan persamaan sebagai berikut:

$$
\begin{aligned}
& \mathrm{z}=\frac{\mathrm{a} \cdot \mathrm{b}}{\sqrt{\mathrm{a}^{2} \mathrm{Sb}^{2}+\mathrm{b}^{2} \mathrm{Sa}^{2}+\mathrm{Sa}^{2} \mathrm{Sb}^{2}}} \\
& \text { Keterangan: } \\
& \mathrm{a} \quad=0,482 \\
& \mathrm{~S}_{\mathrm{a}}=0,075 \\
& \mathrm{~b} \quad=0,496
\end{aligned}
$$




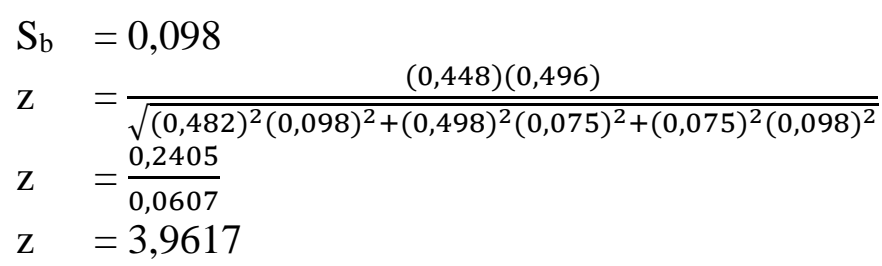

Hasil uji sobel yang dihitung menunjukkan bahwa nilai koefisien $\mathrm{z}$ adalah 3,9617 > 1,96 dengan tingkat signifikansi $0,0001<0,05$ sehingga $\mathrm{H}_{0}$ ditolak dan $\mathrm{H}_{1}$ diterima. Hasil tersebut mengartikan bahwa kepuasan konsumen sebagai variable mediasi dinilai secara signifikan mampu memediasi pengaruh persepsi harga terhadap keputusan pembelian ulang.

Pengaruh antara kualitas produk terhadap kepuasan konsumen dalam penelitian ini diperoleh nilai koefisien $\beta_{1}$ sebesar 0,448 dengan tingkat signifikansi $0,000 \leq 0,05$ sehingga $\mathrm{H}_{1}$ diterima dan $\mathrm{H}_{0}$ ditolak yang mengindikasikan bahwa kualitas produk berpengaruh positif dan signifikan terhadap kepuasan konsumen. Itu berarti, semakin baik kualitas produk pasta gigi Pepsodent maka akan semakin meningkat kepuasan yang dirasakan oleh konsumen pengguna Pepsodent.

Hasil rangkuman penilaian responden yang disajikan dalam deskripsi variabel penelitian menunjukkan bahwa penilaian responden terhadap kualitas produk pasta gigi Pepsodent di Kota Denpasar berada dalam kategori baik. Hasil penelitian ini sejalan dengan penelitian sebelumnya dengan yang dilakukan Suvittawat (2015), Setyo (2017), Widyasari et al. (2017), dan Yanti (2018) yang menunjukkan bahwa kualitas produk berpengaruh positif dan signifikan terhadap kepuasan konsumen.

Pengaruh antara kualitas produk terhadap kepuasan konsumen dalam penelitian ini diperoleh nilai koefisien $\beta_{2}$ sebesar 0,482 dengan tingkat signifikansi $0,000 \leq 0,05$ sehingga $\mathrm{H}_{1}$ diterima dan $\mathrm{H}_{0}$ ditolak yang mengindikasikan bahwa persepsi harga berpengaruh positif dan signifikan terhadap kepuasan konsumen. Itu berarti semakin baik persepsi harga yang ditawarkan pasta gigi Pepsodent kepada konsumen maka akan sesuai dengan manfaat fungsional yang didapat oleh konsumen pasca pembelian Pepsodent.

Hasil rangkuman penilaian responden yang disajikan dalam deskripsi variabel penelitian menunjukkan bahwa persepsi responden terhadap harga yang ditawarkan pasta gigi Pepsodent di Kota Denpasar berada dalam kategori baik. Responden merasa harga yang ditawarkan sesuai dengan kemampuan beli konsumen.

Hasil penelitian ini sejalan dengan penelitian sebelumnya yang dilakukan oleh Deisy et al. (2018), Resti (2016), Budiyanto (2018), Sedjai et al. (2018) yang menunjukkan bahwa persepsi harga berpengaruh positif dan signifikan terhadap kepuasan konsumen.

Pengaruh antara kualitas produk terhadap kepuasan konsumen dalam penelitian ini diperoleh nilai koefisien $\beta_{3}$ sebesar 0,248 dengan tingkat signifikansi $0,003 \leq 0,05$ sehingga $\mathrm{H}_{1}$ diterima dan $\mathrm{H}_{0}$ ditolak yang mengindikasikan bahwa kualitas produk berpengaruh positif dan signifikan terhadap keputusan pembelian ulang. Itu berarti, semakin baik kualitas produk pasta gigi Pepsodent maka akan semakin meningkat pembelian yang dilakukan oleh konsumen pengguna Pepsodent. 
Hasil rangkuman penilaian responden yang disajikan dalam deskripsi variabel penelitian menunjukkan bahwa penilaian responden terhadap kualitas produk pasta gigi Pepsodent di Kota Denpasar berada dalam kategori baik. Sehingga akan terjadi pembelian ulang yang dilakukan oleh konsumen. Hasil penelitian ini sejalan dengan penelitian sebelumnya dengan yang dilakukan Fure et al. (2015), Imam (2015), Nofina (2015), dan (Nasith dkk., (2015) yang menunjukkan bahwa kualitas produk berpengaruh positif dan signifikan terhadap keputusan pembelian ulang.

Pengaruh antara kualitas produk terhadap kepuasan konsumen dalam penelitian ini diperoleh nilai koefisien $\beta_{4}$ sebesar 0,200 dengan tingkat signifikansi $0,017 \leq 0,05$ sehingga $\mathrm{H}_{1}$ diterima dan $\mathrm{H}_{0}$ ditolak yang mengindikasikan bahwa persepsi harga berpengaruh positif dan signifikan terhadap keputusan pembelian ulang. Itu berarti semakin baik persepsi harga yang ditawarkan pasta gigi Pepsodent kepada konsumen maka akan sesuai dengan pembelian yang dilakukan oleh konsumen.

Hasil rangkuman penilaian responden yang disajikan dalam deskripsi variabel penelitian menunjukkan bahwa persepsi responden terhadap harga yang ditawarkan pasta gigi Pepsodent di Kota Denpasar berada dalam kategori baik. Responden merasa harga yang ditawarkan sesuai dengan kemampuan beli konsumen sehingga akan dilakukan pembelian kembali.

Hasil penelitian ini sejalan dengan penelitian sebelumnya yang dilakukan oleh Zahro (2017), Nofina (2015), Apriyani (2013), dan Nasution (2018) yang menunjukkan bahwa persepsi harga berpengaruh positif dan signifikan terhadap keputusan pembelian ulang.

Pengaruh antara kualitas produk terhadap kepuasan konsumen dalam penelitian ini diperoleh nilai koefisien $\beta_{5}$ sebesar 0,496 dengan tingkat signifikansi $0,000 \leq 0,05$ sehingga $\mathrm{H}_{1}$ diterima dan $\mathrm{H}_{0}$ ditolak yang mengindikasikan bahwa kepuasan konsumen berpengaruh positif dan signifikan terhadap keputusan pembelian ulang. Itu berarti, semakin tinggi kepuasan yang dirasakan oleh konsumen setelah menggunakan pasta gigi Pepsodent maka akan semakin mendorong meningkatnya pembelian yang dilakukan oleh konsumen.

Hasil rangkuman penilaian responden yang disajikan dalam deskripsi variabel penelitian menunjukkan bahwa penilaian responden terhadap kepuasan konsumen yang memakai pasta gigi Pepsodent di Kota Denpasar berada dalam kategori baik. Responden merasa puas dengan penggunaan yang dirasakan setelah melakukan pembelian.

Hasil penelitian ini sejalan dengan penelitian sebelumnya yang dilakukan oleh Djumarno et al. (2018), Utama (2015), Pamungkas et al. (2018), Nugrahanto (2015) dan Olii (2016) yang menunjukkan bahwa kepuasan konsumen berpengaruh positif dan signifikan terhadap keputusan pembelian ulang.

Hasil uji pengaruh langsung variabel kualitas produk terhadap keputusan pembelian ulang semula bernilai 0,248 kemudian setelah adanya kepuasna pelanggan sebagai variabel mediasi, nilai pada pengaruh kualitas produk terhadap keputusan pembelian ulang meningkat menjadi sebesar 0,470 Hasil tersebut menunjukkan bahwa kepuasan konsumen memediasi hubungan kualitas produk terhadap keputusan pembelian ulang secara parsial. Nilai uji sobel pengaruh 
kualitas produk terhadap keputusan pembelian ulang melalui kepuasan konsumen adalah sebesar $Z=3.7438>1,96$ dan tingkat signifikansi $0.0002<0,05$. Nilai uji sobel di atas menunjukkan bahwa kepuasan konsumen mampu memediasi pengaruh kualitas produk terhadap keputusan pembelian secara signifikan.

Hasil analisis yang diperoleh dari kedua teknik analisis menunjukkan bahwa semakin meningkat kualitas produk akan semakin meningkat pula keputusan pembelian ulang, disamping itu keputusamn pembelian ulang akan semakin meningkat lagi jika kualitas produk juga mampu meningkatkan kepuasan konsumen pasta gigi Pepsodent di Kota Denpasar.

Hasil penelitian ini sejalan dengan penelitian sebelumnya yang dilakukan oleh Pardede (2015) dalam penelitiannya menyatakan bahwa kualitas produk berpengaruh positif dan signifikan terhadap kepuasan konsumen. Cahya (2018) menyatakan bahwa kualitas produk tidak berpengaruh signifikan terhadap kepuasan pelanggan. Menurut Bowo et al. (2013) kualitas produk mempunyai pengaruh yang bersifat langsung terhadap kepuasan pelanggan dengan meningkatkan kemampuan suatu produk maka akan tercipta keunggulan bersaing sehingga pelanggan menjadi semakin puas yang artinya ada pengaruh positif dan signifikan terhadap kepuasan konsumen dan kualitas produk. Pernyataan tersebut didukung oleh Setyaningrum (2019) kualitas produk merupakan variabel yang paling berpengaruh terhadap keputusan pembelian ulang.

Hasil uji pengaruh langsung variabel persepsi harga terhadap keputusan pembelian ulang semula bernilai 0,200 kemudian setelah adanya kepuasan konsumen sebagai variabel mediasi, nilai pada pengaruh persepsi harga terhadap keputusan pembelian ulang meningkat menjadi sebesar 0,439 Hasil tersebut menunjukkan bahwa kepuasan konsumen memediasi hubungan persepsi harga terhadap keputusan pembelian ulang secara parsial. Nilai uji sobel pengaruh persepsi harga terhadap keputusan pembelian ulang melalui kepuasan konsumen adalah sebesar $Z=3,9617>1,96$ dan tingkat signifikansi $0,0001<0,05$. Nilai uji sobel di atas menunjukkan bahwa kepuasan konsumen mampu memediasi pengaruh persepsi harga terhadap keputusan pembelian secara signifikan.

Hasil analisis yang diperoleh dari kedua teknik analisis menunjukkan bahwa semakin meningkat persepsi harga akan semakin meningkat pula keputusan pembelian ulang, disamping itu keputusamn pembelian ulang akan semakin meningkat lagi jika persepsi harga juga mampu meningkatkan kepuasan konsumen pasta gigi Pepsodent di Kota Denpasar.

Hasil penelitian ini sejalan dengan penelitian sebelumnya yang dilakukan oleh Harjati \& Venesia (2015) Persepsi harga berpengaruh signifikan dan positif terhadap kepuasan konsumen dan keputusan pembelian yang artinya pandangan atau persepsi mengenai harga bagaimana pelanggan memandang harga tertentu tinggi, rendah, memiliki pengaruh yang kuat terhadap maksud membeli dan kepuasan membeli. Sari (2019)Persepsi harga berpengaruh positif dan signifikan terhadap kepuasan konsumen. Sagita (2013) menyatakan bahwa harga berpengaruh signifikan terhadap keputusan pembelian ulang produk. 


\section{SIMPULAN}

Kualitas produk berpengaruh positif dan signifikan terhadap kepuasan konsumen. Hasil ini berarti semakin baik kualitas produk pasta gigi Pepsodent maka akan semakin meningkat pula kepuasan konsumen. Persepsi harga berpengaruh positif dan signifikan terhadap kepuasan konsumen. Hasil ini berarti bahwa apabila semakin baik persepsi terhadap harga yang diberikan pasta gigi Pepsodent maka akan semakin meningkatkan kepuasan konsumen. Kualitas produk berpengaruh positif dan signifikan terhadap keputusan pembelian ulang. Hasil ini berarti bahwa semakin baik kualitas produk pasta gigi Pepsodent maka akan meningkatkan keputusan pembelian ulang dari konsumen. Persepsi harga berpengaruh positif dan signifikan terhadap keputusan pembelian ulang. Hasil ini berarti bahwa semakin baik persepsi harga dibenak konsumen terhadap pasta gigi Pepsodent maka akan meningkatkan keputusan pembelian ualang konsumen. Kepuasan konsumen berpengaruh positif dan signifikan terhadap keputusan pembelian ulang. Hasil ini berarti bahwa semakin baik kepuasan yang dirasakan konsumen maka akan meninggkatkan keputusan pembelian ulang terhadap pasta gigi Pepsodent.

Peran kepuasan konsumen memediasi secara parsial dan signifikan pengaruh kualitas produk terhadap keputusan pembelian ulang. Hasil analisis yang diperoleh dari kedua teknik analisis menunjukkan bahwa semakin meningkat kualitas produk akan semakin meningkat pula keputusan pembelian ulang, disamping itu keputusamn pembelian ulang akan semakin meningkat lagi jika kualitas produk juga mampu meningkatkan kepuasan konsumen pasta gigi Pepsodent di Kota Denpasar. Peran kepuasan konsumen memediasi secara parsial dan signifikan pengaruh persepsi harga terhadap keputusan pembelian ulang. Hasil analisis yang diperoleh dari kedua teknik analisis menunjukkan bahwa semakin meningkat persepsi harga akan semakin meningkat pula keputusan pembelian ulang, disamping itu keputusamn pembelian ulang akan semakin meningkat lagi jika persepsi harga juga mampu meningkatkan kepuasan konsumen pasta gigi Pepsodent di Kota Denpasar.

\section{REFERENSI}

Amstrong, K. dan. (2012). Marketing Management, 14th Edition.

Anwar. (2017). Pengaruh Persepsi Harga dan Kualitas Produk Terhadap Keputusan Pembelian Konsumen Smartphone OPPO pada Toko Handphone Mandiri Medan. E-JURNAL, 2(6), 217-266.

Apriyani, Y. (2013). Pengaruh Brand Image , Harga dan Kualitas Pelayanan Terhadap Keputusan Pembelian Ulang Pizza Hut di Kota Padang. Manajemen, $1(2), 1-10$.

Baruna Hadi Brata, Shilvana Husani, H. A. (2017). The Influence of Quality Products, Price, Promotion, and Location to Product Purchase Decision on Nitchi At PT. Jaya Swarasa Agung in Central Jakarta. Saudi Journal of Business and Management Studies. ISSN 2415-6663 (Print) ISSN 2415-6671 
(Online), 2(4B), 433-445. https://doi.org/10.21276/sjbms

Berger, A. A. (2011). Ads, Fads, and Consumer Culture, Advertising impact on American Character and Society.

Bowo, K. A., Hoyyi, A., \& Mukid, M. A. (2013). Analisis Faktor-Faktor Yang Mempengaruhi Keputusan Pembelian Dan Kepuasan Konsumen Pada Notebook Merek Acer. Jurnal Gaussian, 2(1), 29-38.

Budiyanto, A. (2018). Pengaruh Persepsi Harga, Kualitas Layanan dan Brand Image Terhadap Tingkat Kepuasan Konsumen di PT. Yerry Primatama Hosindo. Jurnal Pemasaran Kompetitif, 1(3), 71-80.

Cahya, N. (2018). Pengaruh Persepsi Harga, Kualitas Produk, Citra Merek dan Layanan Purna Jual Terhadap Keputusan Pembelian dan Dampaknya Terhadap Kepuasan Pelanggan Smartphone Asus Studi Kasus di PT.DATASCRIP. Journal of Entrepreneurship, Management, and Industry, $1(1), 34-46$.

Cahyani, N. S., Lapian, S. L. H. V. J., \& Tumiwa, J. (2017). The Efect of Brand Image, Perceived Price, and Perceived Quality On Consumers' Purchase Decision of Pond's Skin Care Product. EMBA, 5(2), 354-362.

Deisy, Malonda., L. L. dan Y. (2018). Analisis Citra Merek, Harga Produk Dan Kualitas Terhadap Keputusan Pembelian Handphone Samsung Pada Seluruh Gerai Â Gerai Seluler Di It Center Manado. Jurnal EMBA: Jurnal Riset Ekonomi, Manajemen, Bisnis Dan Akuntansi, 6(4), 2288-2297.

Djumarno, Anjani, S., \& Djamaluddin, S. (2018). Effect of Product Quality and Price on Customer Loyalty through Customer Satisfaction. International Journal of Business and Management Invention (IJBMI) ISSN, 7(8), 13-20.

Ferian Ikaryati Putri., dan S. S. (2016). Analisis Diskursus Iklan Pasta Gigi Pepsodent. E-JSurabaya, 04(01), 1-7.

Fure, Fredyanto, L. J. dan T. R. (2015). Pengaruh Brand Image, Kualitas Produk Dan Harga Terhadap Keputusan Pembelian Konsumen Di J.Co Manado. Jurnal Riset Ekonomi, Manajemen, Bisnis Dan Akuntansi, 3(1), 367-377.

Hamza, S. khraim, Sameer, M. A.-J., \& Aymen, S. K. (2014). The effect of perceived value and customer satisfaction on perceived price fairness of airline travelers in Jordan. Universal Journal of Management, 2(5), 186-196. https://doi.org/10.13189/ujm.2014.020502

Harjati, L., \& Venesia, Y. (2015). Pengaruh Kualitas Layanan dan Persepsi Harga Terhadap Kepuasan Pelanggan Pada Maskapai Penerbangan Tiger Air Mandala. E-Journal WIDYA Ekonomika, 1(1), 64-74.

Hartati, S. I. N. S. (2013). Pengaruh Kualitas Produk Terhadap Keputusan Pembelian Ulang Sabun Mandi Merek Shinzui di Kota Palu. Jurnal Ilmu Manajemen, 3(3), 289-298. 
Imam Heryanto. (2015). Analisis pengaruh produk, harga, distribusi, dan promosi terhadap keputusan pembelian serta implikasinya pada kepuasan pelanggan. Jurnal Ekonomi, Bisnis \& Entrepreneurship, 9(2), 80-101.

Isfiandi, Amirudin M., dan A. (2019). Effect of Product Variation, Price, and Customer Experience on Purchase Decision of Ceramic Mulia Tile At Pt. Surya Asia Abadi in Pekanbaru. Jurnal Accounting Business, 4(1), 144-129.

Musa, M. I., Haeruddin, M. I. W., \& Haeruddin, M. I. M. (2018). Customers' repurchase decision in the culinary industry: Do the Big-Five personality types matter. Journal of Business and Retail Management Research, 13(1), 131-137. https://doi.org/10.24052/jbrmr/v13is01/art-13

Nasith, Ahmad Falhan., dan W. H. (2015). Pengaruh Kualitas Produkdan Kesadaran Merek Terhadap Keputusan Pembelian Ulang Melalui Kepuasan Konsumen (Studi pada Konsumen Yamaha Vixion Pt. Mataram Sakti Setiabudi). Jurnal Fakultas Ilmu Dan Sosial Ilmu Politik, 1(1), 1-9.

Nasution, N. P. M. (2018). Pengaruh Harga, Kualitas Pelayanan dan Lokasi Terhadap Keputusan Pembelian Ulang di Coffee Crowd Sun Plaza Medan Pada Mahasiswa FEB USU. Jurnal Repositori Institusi USU, 2(1), 1-14.

Nofina, G. dan F. S. (2015). Pengaruh Bauran Pemasaran Terhadap Keputusan Pembelian Ulang Sepeda Motor Honda Di Pt. Menara Agung Veteran. Jurnal Ilmu Ekonomi. Padang: Sekolah Tinggi Ilmu Ekonomi KBP, 1(2), 1-14.

Nugrahanto, N. F. R. dan N. F. (2015). Pengaruh Kualitas Produk Dan Kesadaran Merek Terhadap Keputusan Pembelian Ulang Melalui Kepuasan Konsumen (Studi Pada Konsumen Yamaha Vixion Pt. Mataram Sakti Setiabudi). Jurnal: Administrasi Bisnis, Fakultas Ilmu Sosial Dan Ilmu Politik, 2(1), 1-9.

Olii, K. R. R. dan I. N. N. (2016). Peran Kepuasan Pelanggan dalam Memediasi Pengaruh Experiential Marketing Terhadap Pembelian Ulang Tiket Pesawat pada Pt Jasa Nusa Wisata Denpasar. Unud, E-Jurnal Manajemen, 5(8), 48354864.

Pamungkas, Agnes Dwiganjar., dan A. W. (2018). The Influence of Brand Image on Repeat Purchase Green Product Pertamax Turbo (Ron 98) with Customer Satisfaction as Intervening Variable. E-Proceeding of Management, 5(2), 2584-2592.

Pardede, R. (2015). Pengaruh Persepsi Harga dan Kualitas Produk Terhadap Keputusan Pembelian Konsumen yang Dimediasi Kepuasan Konsumen. Journal of Business \& Applied Management, 10(1), 56-79.

Prabudi, C. (2014). Analisis Pengaruh Kualitas Produk, Persepsi Harga dan Citra Merek terhadap Keputusan Pembelian Produk Bakpia Wilis di Kota Magelang, Semarang, dan Jogjakarta.

Prasetyo, A. (2015). Persepsi Konsumen Terhadap Kualitas Produk dan Harga Jual Pasta Gigi. 
Resti, D., \& Harry Soesanto. (2016). Pengaruh Persepsi Harga, Kualitas Pelayanan melalui Kepuasan Pelanggan terhadap Minat Beli Ulang pada Rumah Kecantikan Sifra Di Pati. Diponegoro Journal of Management, 5(1), 1-12.

Rizky Iryanita, Y. S. (2013). Analisis Pengaruh Citra Merek, Persepsi Harga, dan Persepsi Kualitas Produk Terhadap Keputusan Pembelian (Studi Pada Konsumen produk ATBM Pekalongan) Rizky Iryanita, Y. Sugiarto 1. Dpponegoro Journal of Management, 6(4), 2288-2297.

Sagita, F. E. (2013). Pengaruh brand image dan harga terhadap keputusan pembelian ulang produk kentucky fried chicken $(\mathrm{kfc})$ di cabang basko grand mall oleh mahasiswa universitas negeri padang. Universitas Negeri Padang, $1(1), 1-8$.

Saleem, B. A., Ghafar, A., Ibrahim, M., Yousuf, M., \& Ahmed, N. (2015). Product Perceived Quality and Purchase Intention withConsumer Satisfaction. Global Journal of Management and Business Research: E Marketing, 15(1), 21-18.

Sari, Meida Ramita., dan R. L. (2019). Pengaruh Persepsi Harga, Kualitas Pelayanan dan Kualitas Produk Terhadap Kepuasan dan Dampaknya Pada Minat Pembelian Ulang Konsumen Keretaapi Kelas Eksekutif Argo Parahyangan. Jurnal Fakultas Ekonomi Dan Bisnis, 15(1), 1-15.

Schiffman, dan K. (2007). Perilaku Konsumen. Edisi Kedua.

Sedjai, Asma, Maliki Samir Baha Dine, B. W. and A. R. (2018). The Effect of Perception Quality/Price of Service on Satisfaction and Loyalty Algerians Customers Evidence Study Turkish Airlines. International Journal of Economics \& Management Sciences, 7(1), 6.

Setyaningrum, F. N. J. W. (2019). ). Pengaruh Kualitas Produk, Promosi dan Citra Merek Terhadap Keputusan Pembelian Ulang (Studi Pada Pelanggan Sarijan Coffee Malang). Jurnal Akuntansi Dan Manajemen, 4(4), 17-2.

Setyo, P. E. (2017). Pengaruh Kualitas Produk, Harga Terhadap Kepuasan Konsumen "Best Autoworks.” Jurnal Manajemen Dan Start-Up Bisnis, 1(6), $755-764$.

Suryani, Siti., dan S. S. R. (2019). Pengaruh Brand Image, Brand Trust, dan Kualitas Layanan Terhadap Keputusan Pembelian Ulang dengan Kepuasan Konsumen Sebagai Variabel Moderating (Studi pada Startup Business Unicorn Indonesia). Journal of Business Studies, 4(1), 1-13.

Suvittawat, A. (2015). Service quality at Thailand???s siam commercial Bank: Chonburi Province. International Journal of Economic Perspectives, 9(4), 21-26.

Swastha, Basu \& Handoko, T. H. (2012). Manajemen Pemasaran: Analisa Perilaku Konsumen.

Tengku, Ezni Balqiah, dan H. S. (2016). Pemahaman Konsep dan Studi Perilaku 
Konsumen dalam Pengembangan Strategi Pemasaran.

Tjiptono, F. (2008). Strategi Pemasaran.

Utama, Mayo Budi., dan N. (2015). Pengaruh Keragaman Produk dan Kualitas Pelayanan terhadap Keputusan Pembelian Ulang melalui Kepuasan Konsumen Sebagai Variabel Intervening (Studi pada Konsumen Gelael Mall Ciputra Semarang). Jurnal: Administrasi Bisnis, Fakultas Ilmu Sosial Dan Ilmu Politik, 1(1), 1-12.

Widyasari, S., Soliha, E., Wuryan, S., \& Damayanti, L. D. (2017). Pengaruh Kualitas Produk, Persepsi Harga dan Citra Merk Terhadap Kepuasan Serta Dampaknya Pada Loyalitas Pelanggan (Studi Empiris Pada Koran Harian Suara Merdeka di Kota Semarang). Jurnal Manajemen Dan Bisnis Indonesia, 8(2), 177-132. https://doi.org/10.31843/jmbi.v5i1.144

Widyastuti, S. (2017). Green Marketing: A Study of the Factors Influencing the Repurchase Decision for Javanony Herbal Products. Asean Marketing Journal, 8(2), 104-115. https://doi.org/10.21002/amj.v8i2.7511

Wifky Muharam, E. S. (2017). Kualitas Produk, Citra Merek, Persepsi Harga dan Keputusan Pembelian Konsumen Konsumen Honda Mobilio. Prosiding Seminar Nasional Multi Disiplin Ilmu Dan Call For Papers Unisbank, 3(3), 755-762.

Yanti, M. (2018). Analysis of The Influence of Trust, Easiness in Shopping, Product Quality to Customer Satisfaction To Increasiness in Shopping Consumer Loyalty Online Shopping. International Journal of Economics, Business and Management Research, 2(4), 50-64.

Zahro, W. A. (2017). Dampak Harga dan Citra Merek Terhadap Keputusan Pembelian Ulang Jilbab pada Outlet Rabbani Collection di Bojonegoro. Jurnal: Pendidikan Tata Niaga (JPTN), 1(1), 55-61. 